総説

特集：遺伝子チップを用いた臨床免疫研究の最前線

\title{
マイクロアレイの臓器移植への応用
}

松井郁一*1,*3，斎浦明夫*2，菅原 寧 彦*1，児玉 龍 彦*3，幕 内 雅 敏*1

\section{Appliance of microarray technology to clinical organ transplantation}

\author{
Yuichi MATSUI $^{* 1, * 3}$, Akio SAIURA*2 ${ }^{*}$ Yasuhiko SUGAWARA*1, Tatsuhiko KodAMA*3 and Masatoshi MAKUUCHI*1 \\ ${ }^{*}$ Department of Transplantation Surgery, Graduate School of Medicine, University of Tokyo, Tokyo, Japan \\ ${ }^{*}$ Department of Surgery, the Cancer Institute Ariake Hospital \\ ${ }^{*}$ Department of Molecular Biology and Medicine, Research Center for Advanced Science and Technology, \\ University of Tokyo
}

(Received March 29, 2005)

summary

\begin{abstract}
Although recent advances in immunosuppressive therapy have dramatically enhanced the early survival of solid organ transplant recipients, acute rejection still occurs in some recipients. Long-term immunosuppressive drug administration, furthermore, entails a number of potentially significant problems such as infection, spontaneous neoplasm and drug toxicity. Alloantigen specific tolerance induction is the ultimate goal in transplant immunology, and can be induced in a rodent model; however, the precise mechanism by which specific tolerance is affected are not clearly understood, and the current immunosuppression regimens have all failed to achieve this goal in a clinical setting.

DNA microarray technology has made it possible to analyze the expression of a large number of genes and revolutionized many areas of biology and medicine. This new technology can provide non-biased, global expressions of tens of thousands of genes simultaneously. Recent studies on gene expression profiles in various diseases, including allograft rejection, have successfully provided important information and new insights into the biological mechanisms of these diseases. In this article, we reviewed these insights, especially with the viewpoint of appliance of microarray technology to clinical solid organ transplantation.
\end{abstract}

Key words_- microarray; transplantation; rejection; tolerance

抄 録

免疫抑制剂の進歩により臓器移植は対象臓器の非可逆的臓器不全に対する確立した治療法の一つとなつている. しかし種々の合併症を併発する危険性も内包しており，急性・慢性拒絶反応もその一つである．臓器移植における 拒絶反応ではアロ主要組織抗原 (MHC) 抗原に対しての特異的免疫反応が主たる原因であるが，現在用いられて いるステロイド，サイクロスポリン A，タクロリムスなどの薬剤はすべて抗原非特異的に作用する，そのため長期 服用による発癌率の増加, ウイルス・真菌などへの易感染性など多くの問題を抱えている. 現在の移植医療の問題 点の一つはこのような抗原非特異的な免疫抑制であり, グラフト抗原特異的な免疫寛容の誘導は移植免疫における 究極の目標である. 近年, 分子生物学の進歩により全遺伝子を網羅的に解析できる DNA マイクロアレイ技術が普 及した，我々はこれまで，DNA マイクロアレイを用いてマウス心移植モデルにおける急性拒絶や免疫寛容の網羅 的遺伝子発現を解析してきた。本稿では，これらのマイクロアレイ技術と今後の移植医療との融合に向けての課題 を検討した.

平成 9 年 10 月に「臓器の移植に関する法律」が 制定施行され，平成 17 年 3 月末まで，日本におい て 35 例の脳死からの臓器提供による移植が行われ た。このように藏器移植は対象臓器の非可逆的藏器

$*_{1}$ 東京大学人工藏器移植外科, $*_{2}$ 癌研究会癌研有明病 院消化器外科, *3東京大学先端科学技術センター分子 生物医学部門
不全に対する確立した治療法の一つとなつている. 治療手段として確立し得たのはサイクロスポリン $\mathrm{A}$ ，タクロリムスといったカルシニュリン阻害剤で ある免疫抑制剂の登場によるところが大きい.しか しながら現在においても臓器移植術後の急性・慢性 の拒絶反応は最も多く起こりえる合併症の一つであ る. 臓器移植における拒絶反応ではアロ主要組織抗 
原 $(\mathrm{MHC})$ 抗原に対しての特異的免疫反応が主た る原因であるが，現在用いられているステロイド， サイクロスポリン $\mathrm{A}$ ，タクロリムスなどの薬剤は すべて抗原非特異的に作用する. そのため長期服用 による発癌率の増加, ウイルス・真菌などへの易感 染性など多くの問題を抱えている．現在の移植医療 の問題点の一つはこのように移植臓器（グラフト） を拒絶から守るために抗原非特異的に免疫抑制を行 つていることであり，グラフト特異的な免度寛容の 誘導は移植免疫での究極目標である。そこで，これ までに行われてきた，DNA マイクロアレイや遺伝 子改変マウスを用いた急性拒絶や免疫寛容の網羅的 遺伝子発現を解析し, 今後の臨床との融合に向けて の課題を検討した.

移植免疫における DNA マイクロアレイ技術の応 用は, 斎浦らがマウス異所性心移植モデルにおいて 急性拒絶反応時の網羅的遺伝子発現解析を行ったの が最初である1)。マウスでは, 同じストレイン間で 移植された心臓は拒絶されず，生着し拍動を続ける (isograft 群)。一方主要組織抗原（MHC）が異な る場合速やかに拒絶され，拍動は停止する（allograft 群)。このような実験系において, 移植心か ら total RNA を抽出し, 逆転写酵素により cDNA を合成, Ambion 社 in vitro transcription によりビ オチンラベルされた cRNA に増幅する. フラグメ ンテーションの後, Affymetrix 社 GeneChip ${ }^{\circledR} に ハ$ イブリダイズし, 専用スキャナーで発現強度を読み とることで, expressed sequence tag (EST) を含め 約 11000 個の遺伝子発現解析が可能である.これま で取られていた仮説に基づいた遺伝子解析 (hypothesis-based gene analysis) から網羅的な発現 解析より仮説を導くという新たな解析手法の登場で もある，斎浦らの研究で Balb/c（H2-d）マウス心 臓を $\mathrm{C} 3 \mathrm{H} / \mathrm{He}(\mathrm{H} 2-\mathrm{k})$ マウス腹部に異所性に移植 する allograft 群の移植心は術後 8 日〜 14 日の間に 完全に拒絶された。一方, $\mathrm{C} 3 \mathrm{H} / \mathrm{He}$ マウス心臓を $\mathrm{C} 3 \mathrm{H} / \mathrm{He}$ マウスに移植した isograft 群では, 全例術 後 100 日以上拍動を続けた. 各群の術後第 $1,3,5$ 病日の移植心から total RNA を抽出し, isograft 群 および $\mathrm{C} 3 \mathrm{H} / \mathrm{He}$ naive 心をコントロールに急性拒絶 モデルである allograft 群の網羅的遺伝子発現解析 を行った．急性拒絶群で発現が上昇している遺伝子 として, MIG, RANTES, IP-10 といったケモカイ ンが同定された。興味深いことに，これらの急性拒

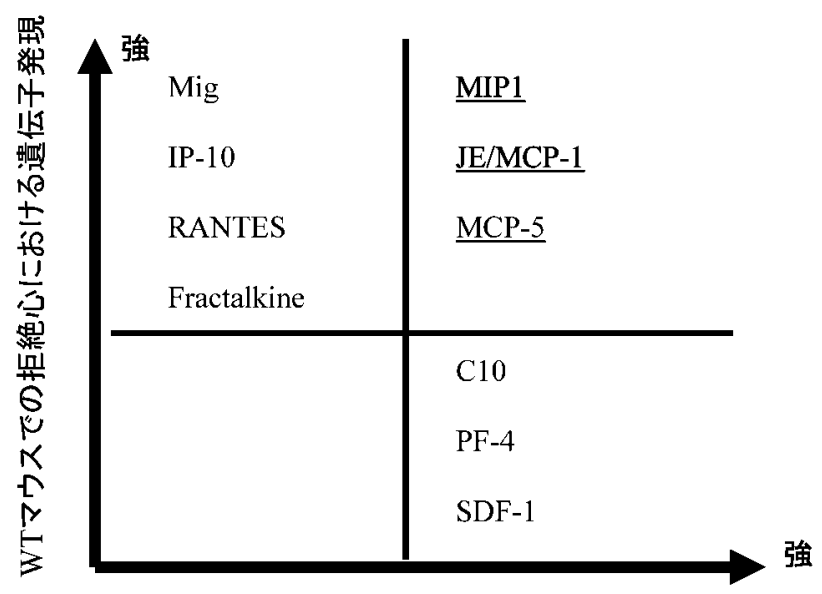

IFN- $\gamma^{-r}$ での拒絶心における遺伝子発現

Figure 1

Upregulated chemokine genes in acute rejection of wild-type and in IFN-gamma-/-mice.

絶群において発現上昇している遺伝子は, 共通して IFN-gamma によって誘導されるという特徵を有し ていた. 次に, IFN-gamma 欠損マウスにおいて急 性拒絶は起こるかどうか，また IFN-gamma 欠損マ ウスに移植した場合での遺伝子発現はどうなってい るのかを検討した ${ }^{2)}$. その結果, IFN-gamma 欠損 マウスにおいても急性拒絶が起こり, むしろグラフ 卜生存期間は IFN-gamma 欠損マウスでの方がやや 短かい傾向にあった。 また IFN-gamma 欠損マウス に植えた移植心では IFN-gammaに依存しない C10, PF-4, SDF-1, CXCR-4 といったサイトカイ ン・ケモカインの遺伝子発現が上昇していることが 同定され, 急性拒絶反応での redundancy の一部が 解明された。 (Figure. 1)

実験動物ではさまざまな免疫寛容誘導の系が確立 されている. $\mathrm{T}$ 細胞が移植抗原を認識する際の costimulatory シグナルを阻害する方法はその一つで ある.

ここで免疫寛容とは，1. 特定の抗原に対して免 疫反応が起こらない. 2. 継続的に免疫抑制剂を投 与する必要がない. 3. その他の抗原に対しては免 疫反応が正常に起こる. という 3 点を満たすものと して定義する3).

我々は, CD 80/86 抗体により, co-stimulatory シ グナルを阻害して得た免疫寛容誘導時における網羅 的遺伝子発現解析を DNA マイクロアレイで行っ $た^{4)}$. グラフト平均生存期間は, 寛容群, isograft 群では 100 日以上, 急性拒絶群で $8.0 \pm 0.7$ 日であ つた $(\mathrm{p}<0.05)$. 興味深いことに寛容群でも組織学 
的に，冠動脈周囲および心筋間に単核球の炎症細胞 浸潤が見られた。急性拒絶群ではより激しい浸潤が 観察され, isograft 群では単核球浸潤はほぼ見られ なかった. (Figure. 2)

遺伝子発現解析は, 術後 7 日, 28 日, 70 日目の

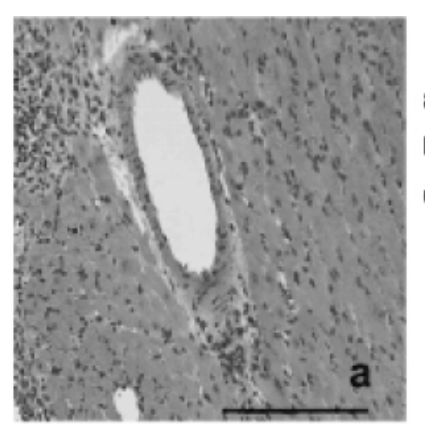

\section{a. Tolerizing allograft on day 7 b. Rejecting allograft on day 7 c. Isograft on day 7}
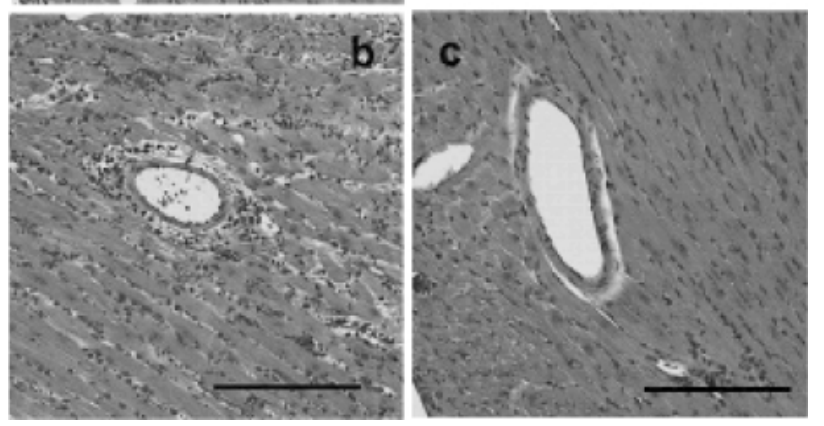

Figure 2

Histology of transplanted heart $(\mathrm{A}-\mathrm{C})$. On day 7, transplanted grafts were harvested and processed for hematoxylin and eosin staining.

Interestingly, on day 7, tolerizing allografts exhibited a slightly diffuse, perivascular, or interstitial infiltration of mononuclear cells.
グラフトより total RNA を抽出し, Affymetrix 社 GeneChip ${ }^{\circledR}$ U74AV2 を用い斎浦らと同様の方法で 行った。その結果, 寛容群では, 64 遺伝子が isograft 群より, 16 遺伝子が拒絶群より発現が上昇 し， 2 遺伝子が免疫寛容特異的遺伝子として同定さ れた。 また，興味深いことに斎浦らによって同定さ れた急性拒絶群で上昇が見られる IFN-gammaによ つて誘導される Mig, RANTES といった炎症性ケ モカイン遺伝子の発現は急性拒絶群だけでなく寛容 群でも上昇しており，しかもこれらは，術後 7 日目 のみならず免疫寛容誘導後 70 日目においても発現 上昇が持続していた。（Figure. 3）つまりこれら炎 症性ケモカインの遺伝子発現上昇があっても, 免疫 寛容の導入および維持は保たれることが in vivo で 示された. 病理学的所見および遺伝子発現解析では 上記のように急性拒絶群と免疫寛容群で類似してい るところはあるものの, 一方でグラフトは拒絶され 拍動を停止し, 他方で移植心は拍動を続けている. その結果の差を生んでいるメカニズムの一つとして, $\mathrm{T}$ 細胞の Activation-induced cell death (AICD) の 役割が重要と思われる。 AICD とは, 抗原が $\mathrm{T}$ 細 胞に提示され刺激を受け続けた場合に起こる, いわ ばリンパ球の homeostasis を保つ機構で, 大部分が Fas-FasL により開始される細胞死である. Lenardo らによると5), T 細胞の AICD が免疫寛容誘導には 必要であり, 一方 IL-2 や IFN-gamma は AICD を 克進させる6,7) との報告もある。どのように免疫寛
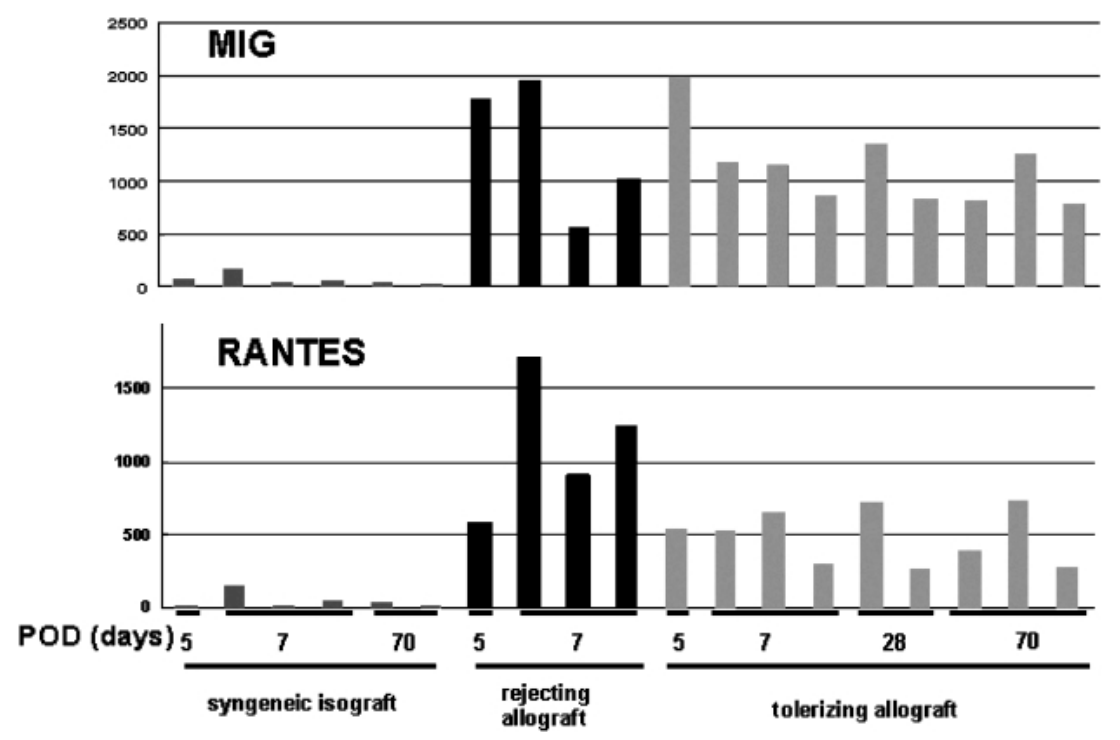

Figure 3

Values of the average difference of representative chemokine genes, MIG and RANTES. The average difference of not only the tolerizing but also rejecting cardiac allografts on day 7 was three times more than that of the syngeneic isografts on day 7 .

MIG, monokine induced by IFN- $\gamma$; RANTES, regulated on activation normal $\mathrm{T}$ cell expressed and secreted. 
容群で AICD が graft acceptance に作用しているか は今後の課題である.

human を対象に比較的大規模に藏器移植の遺伝 子発現解析を行った研究としては, 2003 年 Sarwal らにより行われた，59例の小児腎移植患者の遺伝 子発現解析がある8). 解析された 59 例の内訳は, 急性拒絶 21 例, 慢性拒絶 (chronic allograft nephropathy：CAN） 16 例, 薬剤性腎障害 15 例で あった。急性拒絶群で NF-kB や IFN gamma によ り誘導される Apoptosis 関連遺伝子，CD20，CD74， immunoglobulin heavy and light chain といった B 細 胞関連遺伝子の発現上昇が見られた。一方，CAN 群では, cyclinA2や cyclinB1, cell division cycle と いった細胞増殖や細胞周期に関連する遺伝子の発現 上昇が見られた，薬剤性腎障害の患者では，annexin $\mathrm{V}$ や TGF beta といった自然免疫関連遺伝子の発 現が上昇していた。 Sarwalらは，組織中の total RNA を linear に amplify することで，ヒト腎移植 後の急性拒絶（acute rejection：AR）および慢性拒 絶（chronic allograft nephropathy:CAN）の生検 の一部である微量組織より gene profile を解析する 方法を確立した． 組織所見では同じ急性拒絶反応に 診断される中にも，遺伝子発現上は 3 つのサブタイ プに分別されることを示し，この中で CD20 陽性の $\mathrm{B}$ 細胞の浸潤が見られる群が有意にステロイド治療 に対しての抵抗性を示し，より高率に移植片廃絶に 結びつくとしており，DNA マイクロアレイが急性 拒絶反応をより治療効果を予測しうる診断に寄与す る可能性があることを示唆した。

ケモカインの局在に関して 2001 年 Goddard ら は99, humanの肝移植患者を対象に興味深い研究を 行っている．肝移植術後少なくとも 2 回以上ステロ イド治療に対し抵抗を示した慢性拒絶患者を対象 に，末梢血単核球から単離したリンパ球および再移 植の際摘出されたグラフト肝を解析している. flow cytometryおよび免疫染色によりケモカイン CXCR3 のライガンドである IP-10, MIG は拒絶患 者の肝類洞内皮での発現が上昇しており, 門脈内皮 ではITACの発現上昇がみられた。また胆管上皮 では CXCR4 のライガンドである SDF-1 の発現上 昇がみられることを同定し，各部位で発現上昇して いるケモカインがリンパ球リクルートに関与してい ることを示した.
2003 年 Scherer らは10), human 腎移植患者の慢 性拒絶の早期診断に遺伝子チップが有用である可能 性を示唆した。糸球体腎炎, 腎孟腎炎などの endstage 腎疾患に腎移植を施行した患者すべてに，プ ロトコールバイオプシーとして移植手術時, 術後 6 ケ月, 術後 12 ケ月の計 3 回腎生検を施行してい る. 研究対象は術後 6 ケ月の時点で拒絶反応は起こ つていない患者 17 名で，その後術後 12 ケ月の段階 で慢性拒絶を起こした患者と起こしていない患者の 2 群に分け，両群の術後 6 ケ月の拒絶が起こってい ない時点での腎生検検体から RNA を抽出し, 遺伝 子発現プロファイルを pre CR (chronic rejection) 群と Control 群として網羅的に比較解析している. 慢性拒絶群で発現上昇している遺伝子として, cytokeratin 15, hoxB7, NPRL2, OS9, G-protein gamma 7, OBCML (opiate-binding protein-cell adhesion molecule-like), および EST2 種の計 8 遺伝子を, 発現下降している遺伝子として, hoxA7, prolactin receptor (PRLR) の 2 遺伝子を挙げている. これ ら 10 遺伝子の組夕合わせパターンから $88 \%$ の特異 度で慢性拒絶の発生が予知できるとし, Prognostic marker としての有用性を示唆した.

2002 年 Stegall らは11), ラット異所性心移植モデ ルにて Affymetrix 社 GeneChip U34A を用い, 急性 拒絶反応の解析を行っている. 術後第 3 , 第 5 , 第 7 日の遺伝子プロファイルを調べ, 発現上昇遺伝子 として, Allograft inflammatory factor-1, Interferon regulatory factor-1, TGF-beta 1 を同定し, 発現が 抑制されている遺伝子として, Decorin, SC1 を同 定した。 Decorin は TGF-beta 1 のアンタゴニスト で，Decorin が抑制されることで TGF-beta 1 によ る炎症や繊維化の反応が充進するのではと考察して いる.また，SC1 は SPARC と homology を有し， 接着因子を阻害する作用をしているとし，この発現 が抑制されることでグラフトへの接着因子の作用が 強化されるのではと推察している.

カルシニュリン阻害剂の作用機序に関し，2003 年 Erickson らは12), ラット異所性心移植モデルに おいて，遺伝子チップを用い網羅的に解析してい る. 同系移植である isograft 群をコントロールとし て，1. 無治療 allograft 群（通常の急性拒絶モデ ル), 2. タクロリムス投与群, 3. サイクロスポリン 投与群の 3 つの群で遺伝子発現を解析している.こ 
の研究では, 無治療 allograft 群で上昇し, タクロ リムス群, シクロスポリン群両群で発現が低下して いる遺伝子群をカルシニュリン阻害の免疫抑制剂が 作用していると遺伝子群とし，8遺伝子を同定し た。これら 8 遺伝子には, IL-2 receptor alpha, Inducible nitric oxide synthase (iNOS2), TGF-beta receptor 3 , interferon regulatory factor 1 (IRF-1), Interferon（IFN） gammaなどがあった。これらは マクロファージ，ナチュラル・キラー細胞, cytotoxic $\mathrm{T}$ 細胞活性に必要な遺伝子であり, 急性拒絶 反応は宿主の $\mathrm{T}$ 細胞で媒介されるカスケードより 起こり, カルシニュリン阻害剤はこれらのカスケー ドのいくつかを阻害することで拒絶反応を抑制して いるという機序を証明した。

DNA マイクロアレイは一度に何千もの遺伝子発 現を解析しえるという点で, 大変強力な手段である が，結果を解釈するにあたり留意すべき事項があ る. まず第 1 に，費用の面で実験および研究施行回 数が限定されてしまうことが多く，偽陽性の結果が 出てしまう可能性を含んでいる，第 2 に，マイクロ アレイで解析している mRNA の発現と対応する夕 ンパクの相関が必ずしも直線的でない場合がある, ということである．ただし，Celis らによると細胞 内に mRNA が存在しない場合, 対応するタンパク 量もそれほど多くないレベルである13)。最後に遺伝 子には DNA マイクロアレイの結果で発現量が少な くても, biological には影響の強いものが存在する 可能性がある.このような遺伝子では, 変化の幅が 小さくても十分意義のある反応である場合があり, このような変化は他の強力な反応にマスキングされ， DNA マイクロアレイによる発現解析では detect さ れない可能性がある.

今後の課題としては, グラフトに浸潤しているリ ンパ球（graft infiltrating cell : GIC）に絞つての遺 伝子発現解析から拒絶発症, 寛容誘導・維持のメカ ニズムの考察，GFP マウスやノックアウトマウス を用いたアレイデータの集積およびそこからのメカ ニズムの検討などが考えられる.

まとめると, DNA マイクロアレイは臓器移植の 臨床分野では, 1. 診断：急性または慢性拒絶反応 の分子生物学的診断, 2. 新規治療薬：メカニズム を解明し, 分子標的分子を同定するといつた, 診断 および治療の面で応用の可能性を備えている.

\section{文献}

1) Saiura, A., et al. : A comparison of gene expression in murine cardiac allografts and isografts by means DNA microarray analysis. Transplantation, 72 : 320-329, 2001.

2) Saiura, A., et al. : Detection of an up-regulation of a group of chemokine genes in murine cardiac allograft in the absence of interferongamma by means of DNA microarray. Transplantation, 73 : 1480-1486, 2002.

3) $\mathrm{Li}, \mathrm{X} . \mathrm{C}$., et al. : $\mathrm{T}$ cell death and transplantation tolerance. Immunity, 14 : 407-416, 2001.

4) Matsui, Y., et al. : Identification of gene expression profile in tolerizing murine cardiac allograft by costimulatory blockade. Physiol Genomics, 15 : 199-208, 2003.

5) Lenardo, M. J. : Interleukin-2 programs mouse alpha beta $\mathrm{T}$ lymphocytes for apoptosis. $\mathrm{Na}$ ture, 353 : 858-861, 1991.

6) Dalton, D. K., et al. : Interferon gamma eliminates responding CD4 $\mathrm{T}$ cells during mycobacterial infection by inducing apoptosis of activated CD4 T cells. J Exp Med, 192 : 117122, 2000.

7) Badovinac, V. P. and J. T. Harty : Adaptive immunity and enhanced $\mathrm{CD} 8+\mathrm{T}$ cell response to Listeria monocytogenes in the absence of perforin and IFN-gamma. J Immunol, 164 : 6444-6452, 2000.

8) Sarwal, M., et al. : Molecular heterogeneity in acute renal allograft rejection identified by DNA microarray profiling. $N$ Engl J Med, 349 : 125-138, 2003.

9) Goddard, S., et al. : Differential expression of chemokines and chemokine receptors shapes the inflammatory response in rejecting human liver transplants. Transplantation, 72 : 19571967, 2001.

10) Scherer, A., et al. : Early prognosis of the development of renal chronic allograft rejection by gene expression profiling of human protocol biopsies. Transplantation, $75: 1323-1330$, 2003.

11) Stegall, M., et al. : Gene expression during acute allograft rejection : novel statistical analysis of microarray data. Am J Transplant, 2 : 913-925, 2002.

12) Erickson, L. M., et al. : Microarray-based gene expression profiles of allograft rejection and immunosuppression in the rat heart transplanta- 
tion model. Transplantation, $76: 582-588$, 2003.

13) Celis, J. E., et al. : Gene expression profiling : monitoring transcription and translation products using DNA microarrays and proteomics. FEBS Lett, $480: 2-16,2000$. 